\title{
Diagnosis of Ink Disease of Chestnut by Molecular Identification of Associated Phytophthora Species
}

\author{
M.E. Gouveia, V. Coelho and A. Choupina \\ Instituto Politécnico de Bragança \\ Campus Sta. Apolónia, Apt 172 \\ 5300-855 Bragança \\ Portugal \\ R. Hermosa and E. Monte \\ Universidade de Salamanca \\ Campus Unamuno, Avda Campo Charro \\ 37007 Salamanca \\ España
}

\author{
C.G. Abreu \\ Universidade de Trás-os-Montes \\ e Alto Douro, Apt. 1013 \\ 5000-911 Vila Real \\ Portugal
}

Keywords: $P$. cinnamomi, $P$. cambivora, Phytophthora detection, ITS-RFLP identification

\begin{abstract}
For diagnostic proposes of ink disease, chestnut orchards with symptoms of decline or sudden death of trees were sampled by soil baiting techniques and selective agar media $\left(\mathrm{P}_{10} \mathrm{VPH}\right)$. Thirty-six Phytophthora isolates were obtained. One isolate per tree and three or two isolates from the soil of the same plant were considered for molecular identification. Genomic DNA was extracted from all the isolates and from the reference strain $P$. cinnamomi CECT 2965. The ribosomal regions ITS1, 5.8S and ITS2 were amplified with the universal primer pair ITS6 (Cooke and Duncan, 1997) and ITS4 (White et al., 1990) by PCR. The amplified fragment $(900 \mathrm{pb})$ was digested with restriction enzymes $M s p I$, AluI and TaqI. Two different patterns of fingerprinting were obtained with enzymes TaqI and AluI (type I and II) and three different patterns with MspI (type I, Ia, II). The fingerprinting of each isolate was compared with database of CABI by public web access. Type I and Ia (14 isolates) were assigned to $P$. cinnamomi and type II (4 isolates) was assigned to $P$. cambivora. Molecular methods provide a rapid means of Phytophthora species identification associated with ink disease of chestnut and will provide a useful tool for etiological and epidemiological studies of this important disease of chestnut.
\end{abstract}

\section{INTRODUCTION}

Ink disease of chestnut, which causes decline and death of chestnut trees of all ages, is responsible for severe losses and represents a serious threat in all chestnut areas. Both, Phytophthora cinnamomi and Phytophthora cambivora are frequently associated with ink disease of chestnut (Pimentel, 1947; Crandall, 1950). More complex etiology can be envisaged as other Phytophthora species have been associated with ink disease of chestnut: P. megasperma was found on ink diseased chestnut trees by Grente (1961) and Vittraino et al. (2001) isolated $P$. cactorum, $P$. citricola and $P$. cambivora from the soil under the canopy of diseased chestnut trees in central Italy.

The objectives of this work were to obtain a great number of Phytophthora isolates associated with ink disease syndrome, to identify them to species level by using the ITS-RFLP approach and to elucidate the complex etiology of ink disease of chestnut.

Soil-borne Phytophthora are extremely difficult, if not impossible, to detect on old or decayed plant tissues, unless special techniques are used (Tsao, 1990). Unfortunately, these types of plant tissues are the most frequent in field situations when dealing with ink disease of chestnut. To overcome this constraint baiting techniques and selective agar media for detection and isolation were used.

Phytophthora identification is also a difficult subject. Phytophthora species identification is primarily based on morphological criteria. Plasticity of morphological characters and overlapping of metric characteristics hamper identification. It also requires 
considerable expertise to produce the various stages through cultural manipulations and to recognise fine morphological differences. Molecular methods provide a new approach for Phytophthora species identification (Lee and Taylor, 1992; Liew et al., 1998; Cooke and Ducan, 1997; Cooke et al., 2000). In this work the method used was proposed by Cooke and Ducan (1997) and was based on the amplification PCR of the entire 5.8S rDNA gene and both ITS1 and ITS2 with specific Oomycetes primers, ITS6 (Cooke and Ducan, 1997) and ITS4 (White et al., 1990) followed by enzymatic restriction with MspI, AluI and TaqI and analysis of the restriction fragments.

\section{MATERIALS AND METHODS}

\section{Detection and Purification of Phytophthora Isolates}

Chestnut trees with ink disease symptoms were surveyed in three chestnut orchards in the south Bragança region (Rossas, Arufe and Paredes). Four old chestnut trees in adult orchards - Rossas (trees more than 30 years old), three chestnut trees in young orchards - Arufe (8-10 years old) and eight recently transplanted plants - Paredes, were sampled.

All plant tissue for isolation of Phytophthora species was carefully rinsed for 1015 min under tap water (decayed tissue of roots and collar bark was rinsed overnight) blotted dry on filter paper and little segments were placed in Petri dishes on selective medium $\mathrm{P}_{10} \mathrm{VPH}$ (Tsao and Guy, 1977) (PDA (Difco) $39 \mathrm{~g} \mathrm{~L}^{-1}$ instead of CMA, pimaricine - $10 \mathrm{mg}$, vancomycine - $200 \mathrm{mg}$, PCNB - $100 \mathrm{mg}$, hymezaxol - $50 \mathrm{mg}$ ). Dishes were incubated in the dark at $20-22^{\circ} \mathrm{C}$ and were checked daily for characteristic coralloid and cenocytic hypha. Transfers from colonies were maid to $\mathrm{P}_{10} \mathrm{VPH}$ for isolate purification. Pure isolates were kept on PDA $\left(39 \mathrm{~g} / \mathrm{L}\right.$, Difco) or in sterile water at $15^{\circ} \mathrm{C}$.

In recently planted orchards with a great number of dead plants (Paredes) soil near and around roots of dead plants was sampled. Soil for baiting tests was mixed and diluted with sterile distilled water $(1: 4)$ and baited with discs of chestnut leaves, floated on the surface of the water. After $48 \mathrm{~h}$ of incubation at laboratory conditions, the leaves were blotted on filter paper, and placed on $\mathrm{P}_{10} \mathrm{VPH}$. In adult orchards where newly infected tissue was difficult to sample the "natural bait" was applied. Young chestnut plants, germinated nuts under the canopy, with and without symptoms of the ink disease were used as natural bait for Phytophthora detection. The isolation and purification of the parasites on bait tissue was the same as described above.

\section{Genomic DNA Extraction, PCR Amplification and Enzyme Digestion}

Each isolate was grown on cellophane-PDA for 3-4 days. Mycelium was scraped from the surface and genomic DNA was immediately extracted as described by Cooke and Ducan (1997). PCR reactions were performed in a total volume of $25 \mu 1$ with the universal primer pair ITS6 (Cooke and Ducan, 1997) and ITS4 (White et al., 1990) at 2 $\mu \mathrm{M}$ for the amplification of the entire 5.8S rDNA gene and both ITS1 and ITS2. Each reaction contained $100 \mu \mathrm{M}$ dNTPs, $1.5 \mathrm{mM} \mathrm{MgCl}_{2}, 1$ unit of Taq polymerase (Taq polymerase, Promega) $2.5 \mu \mathrm{l}$ of buffer supplied with kit and $2.5 \mu \mathrm{l}$ of BSA (Bovine Serum Albumin) diluted in $10 \mathrm{mg} \mathrm{ml}^{-1}$ before use and $1 \mu \mathrm{l}$ of extracted DNA template. For the negative control, water instead of template DNA was included in each experiment.

Thermal cycler (UNOII, Biometra ${ }^{\circledR}$ ) starting with a single step at $94^{\circ} \mathrm{C}$ for $3 \mathrm{~min}$ was followed by 35 cycles of $55^{\circ} \mathrm{C}-30 \mathrm{~s}, 72^{\circ} \mathrm{C}-60 \mathrm{~s}$ and $94^{\circ} \mathrm{C}-30 \mathrm{~s}$ and a final single step at $72^{\circ} \mathrm{C}$ for $10 \mathrm{~min}$. Amplicons were analysed by electrophoreses in $1 \%$ agarose gels on TAE and visualized by ethidium bromide staining.

A $10 \mu \mathrm{l}$ sample of the PCR product was digested with restriction enzymes - AluI, $M s p I$ and TaqI according to enzymes manufacturer. The reactions were performed at $37^{\circ} \mathrm{C}$ overnight. Digested DNA was electrophoresed on $2.5 \%$ NuSieve (TaqI digest was electrophoresed at 3.5\% NuSieve). The gels were stained with $\mathrm{EtBr}$ for polymorphism analyses. The size of the restriction fragments, in base pairs, was measured from the gels and compared to standard ladders. The gels were photographed under UV light and digital 
images were scanned by Eagle $\mathrm{Eye}^{\mathrm{TM}}$ (Strategene). The pattern fingerprint of each enzyme digest was compared to CABI-Bioscience database (www.phytid.org) for isolate identification at species level.

\section{RESULTS}

\section{Detection and Purification of Phytophthora Isolates}

Thirty-six Phytophthora isolates were obtained from the fifteen sampled trees and soil of surveyed orchards. In all chestnut orchards and on all chestnut trees with ink disease symptoms, Phytophthora species were detected. Only one isolate per tree and three or two isolates obtained from the soil around the same diseased plant were included for molecular identification (Table 1).

\section{Genomic DNA Extraction, PCR Amplification and Enzyme Digestion}

The quality of the genomic DNA was assessed by gel electrophoresis. With the universal primer pair ITS6 (Cooke and Ducan, 1997) and ITS4 (White et al., 1990) all Phytophthora isolates yielded a single bright fragment of approximately $900 \mathrm{bp}$.

Three restriction patterns were shown after digestion with MspI: I, Ia, II; two restriction patterns with AluI: I, II and two restriction patterns with TaqI. Fragment sizes of each pattern are presented in Table 2.

Three groups of isolates are defined by restriction patterns: thirteen isolates were group I (Pr112, Pr115, Pr120, Pr123, Pr124, Pr125, Pr128, Pr129, Pr130, Ar104, R105, R106, R108), four isolates were group II (Pr135, Ar101, Ar102, R107) and one isolate, Pr122, was included in a Ia group. P. cinnamomi (CECT-2965) was included in group I isolates. Generated restriction patterns of each group of isolates were compared with CABI - Bioscience database of Phytophthora ITS fingerprint and identification at species level was obtained by percent (\%) similarity with reference strain pattern in database. Isolates of Group I and II have a characteristic pattern and identification was accurately obtained. Isolate (Pr122) has a different restriction pattern with MspI but this pattern did not modify the relative percentage of species similarity and so did not affect identification. Isolates of Group I and Ia (fourteen isolates) were identified as $P$. cinnamomi and the four isolates of group II have been identified as $P$. cambivora.

\section{DISCUSSION}

Ink disease of chestnut has been present in Portugal since 1838 (Fernandes, 1966). It drastically reduces chestnut area and a great number of foci are present on all chestnut regions. The disease is difficult to control and is a real constraint for establishment of new groves and conservation of old ones.

In this study, Phytophthora species were isolated by classical methods from all trees with ink disease symptoms and from soil around dead young plants. In old chestnut orchards with symptoms of decline or sudden death of trees, newly infected plant tissue is difficult to sample. In this situation the detection was performed on young plants which had germinated under the canopy (lost nuts of previous year) with and without symptoms of ink disease. These plants were natural bait for Phytophthora species in the orchard soils and were a useful technique for extensive survey in old chestnut orchards. Baiting the soil with chestnut leaves is also an efficient technique and provides many Phytophthora isolates from soil around decayed and dead roots.

Phytophthora identification by ITS-RFLP is an amenable method for Phytophthora identification at species level. P. cambivora and P. cinnamomi with fine morphological discrimination were accurately identified by this molecular approach.

In this study, $P$. cinnamomi and $P$. cambivora were identified in all sampled orchards. $P$. cinnamomi was the most frequently isolated from roots and collar stem bark of 2-3 year-old chestnuts and on recently germinated seedlings used as natural bait in old chestnut orchards. P. cambivora (R107) was recovered only once from these young seedlings. P. cambivora was predominantly obtained from chestnut trees 8-10 years old with 
characteristic necrosis on collar stem, but P. cinnamomi (Ar104) also was isolated in this group of trees. In soil baited with chestnut leaves, the two Phytophthora species were also identified and once more $P$. cinnamomi was the preponderate species and only one isolate was identified as $P$. cambivora.

Molecular methods of Phytophthora identification which allow more rapid and accurate identification of Phytophthora isolates will facilitate more extensive surveys and will improve the knowledge of Phytophthora species distribution in soil and plants, its seasonal activity, its aggressiveness and means of survival and its ability to build up inoculum in soil.

\section{Literature Cited}

Cooke, D., Drenth, A., Duncan, J., Wagels, G. and Brasier, C. 2000. A molecular Phylogeny of Phytophthora and related Oomycetes. Fungal Genetics Biol. 30:17-32.

Cooke, D.E.L. and Duncan, M.J. 1997. Phylogenetic analysis of Phytophthora species based on ITS1 and ITS2 sequences of ribosomal RNA gene repeat. Mycol. Res. 101(6):667-677.

Crandall, S.B. 1950. The distribution and significance of the chestnut root rot Phytophthoras, P. cinnamomi and P. cambivora. Plant Disease Reporter 34:194-196.

Fernandes, C.T. 1966. A "Doença da Tinta" dos castanheiros. Parasitas do género Phytophthora de Bary. Direcção Geral dos Serviços Florestais e Aquicolas, Alcobaça.

Grente, J. 1961. La maladie de l'encre du chataignier. II-les agents pathogènes: Phytophthora cambivora et Phytophthora cinnamomi. Ann. Epiphyties 12:25-59.

Lee, S. and Taylor, J. 1992. Phylogenie of five Fungus-like Protoctistan Phytophthora species inferred from the internal transcribed spacers of ribosomal DNA. Mol. Biol. Evol. 9:636-653.

Liew, E., Maclean, D. and Irwin, A. 1998. Specific PCR based detection of Phytophthora medicaginis using the intergenic spacer region of the ribosomal DNA. Mycol. Res. 102:73-80.

Pimentel, A. 1947. A Phytophthora cinnamomi Rands, um outro agente extremamente virulento da "doença da tinta" do castanheiro. Separata da Agronomia Lusitana, Vol IX, Tomo III. p.181-191.

Tsao, H.P. and Guy, O.S. 1977. Inhibition of Mortierella and Pythium in a Phytophthora isolation medium containing hymexazol. Phytopathology 50:717-801.

Tsao, P. 1990. Why many Phytophthora root rots and crown rots of tree and horticultural crops remain undetected. Bulletin OEPP/EPPO Bulletin 20:11-17.

Vettraino, A.M., Natili, G., Anselmi, N. and Vanini, A. 2001 Recovery and pathogenicity of Phythophthora species associated with a resurgence of Ink Disease in Castanea sativa in Italy. Eur. J. Plant Pathol. 50:90-96.

White, T.J., Bruns, T., Lee, S. and Taylor, J. 1990. Amplification and direct sequencing of fungal ribosomal RNA genes for phylogenetics. p.315-322 In: M.A. Innis, D.H. Gelfand, J.J. Sninsky and T.J. White (eds.), PCR Protocols: A Guide to Methods and Applications, Academic Press, New York. 
$\underline{\text { Tables }}$

Table 1. Phytophthora isolates detected in chestnut trees with ink disease symptoms, sites, sampled tissue and orchard type.

\begin{tabular}{|c|c|c|c|}
\hline Site & Isolate number & Sample tissue & Orchard type \\
\hline Paredes & $\operatorname{Pr} 112$ & Roots/collar bark & Recently transplanted \\
\hline “ & $\operatorname{Pr} 115$ & “ & (2-3 years old) \\
\hline \multirow[t]{9}{*}{ “" } & $\operatorname{Pr} 120$ & “ & \\
\hline & $\operatorname{Pr} 122$ & “ & \\
\hline & $\operatorname{Pr} 123 *$ & Bait soil technique & \\
\hline & $\operatorname{Pr} 124^{*}$ & “ & \\
\hline & $\operatorname{Pr} 125^{*}$ & “ & \\
\hline & $\operatorname{Pr} 128+$ & “ & \\
\hline & $\operatorname{Pr} 129+$ & “ & \\
\hline & $\operatorname{Pr} 130$ & 6 & \\
\hline & $\operatorname{Pr} 135$ & “ & \\
\hline \multirow[t]{3}{*}{ Arufe } & Ar101 & Collar bark & Young \\
\hline & Ar102 & “ & (8-10 years old) \\
\hline & Ar104 & “ & “ \\
\hline \multirow[t]{4}{*}{ Rossas } & R105 & "Natural bait" & Adult \\
\hline & R106 & (roots of young plants) & (>30 years old) \\
\hline & R107 & & \\
\hline & R108 & & \\
\hline
\end{tabular}

* + Isolates from soil around the same plant

Table 2. Restriction fragment sizes (bp) from the DNA region ITS1, 5.8S and ITS2 of Phytophthora isolates amplified with primer pair ITS6 (Cooke and Ducan, 1997) and ITS4 (White et al., 1990) with restriction enzymes MspI, AluI and TaqI.

\begin{tabular}{cl}
\hline Restriction patterns & Fragment sizes (bp) \\
\hline Digestion with MspI & \\
I & $147,163,221,407$ \\
Ia & $147,163,221,394,407$ \\
II & $146,166,221,294,407$ \\
Digestion with AluI & $188,207,543$ \\
I & 188,750 \\
II & \\
Digestion with TaqI & $59,90,117,125,150,180,190$ \\
I & $90,120,125,150,194$ \\
II & \\
\hline
\end{tabular}


